\title{
Environmental constraints and pathologies that modulate equine placental genes and development
}

\author{
Morgane Robles ${ }^{1,2,3}$, Shavahn Loux $\mathbb{1}^{4}$, Amanda M de Mestre $\mathbb{B}^{5}$ and Pascale Chavatte-Palmer(12,3 \\ ${ }^{1}$ INRS Centre Armand-Frappier et Santé Biotechnologique, Laval, Québec, Canada, ${ }^{2}$ Université Paris-Saclay, UVSQ, \\ INRAE, BREED, Jouy-en-Josas, France, ${ }^{3}$ Ecole Nationale Vétérinaire d'Alfort, BREED, Maisons-Alfort, France, \\ ${ }^{4}$ Maxwell H. Gluck Equine Research Center, Department of Veterinary Science, University of Kentucky, Lexington, \\ Kentucky, USA and ${ }^{5}$ Department of Comparative Biomedical Sciences, Royal Veterinary College, Hawkshead Lane, \\ Hatfield, UK
}

Correspondence should be addressed to M Robles; Email: morgane.robles@gmail.com

\begin{abstract}
Equine placental development is a long process with unique features. Implantation occurs around 40 days of gestation (dpo) with the presence of a transient invasive placenta from 25-35 to 100-120 dpo. The definitive, non-invasive placenta remains until term (330 days). This definitive placenta is diffuse and epitheliochorial, exchanging nutrients, gas and waste with the endometrium through microvilli, called microcotyledons. These are lined by an external layer of haemotrophic trophoblast. Moreover, histotrophic exchange remains active through the histotrophic trophoblast located along the areolae. Placental development is dependent on the maternal environment that can be affected by several factors (e.g. nutrition, metabolism, age, embryo technologies, pathologies) that may affect fetal development as well as long-term offspring health. The first section of the review focuses on normal placental development as well as definitive placental structure. Differences between the various regions of the placenta are also highlighted. The latter sections provide an overview of the effects of the maternal environment and reproductive pathologies, respectively, on trophoblast/placental gene expression and structure. So far, only pre-implantation and late gestation/term data are available, which demonstrate important placental plasticity in response to environmental variation, with genes involved in oxidative stress and tissue differentiation mostly involved in the pre-implantation period, whereas genes involved in feto-placental growth and nutrient transfers are mostly perturbed at term.

Reproduction (2022) 163 R25-R38
\end{abstract}

\section{Introduction}

Gestation in the horse takes approximately 11 months; however, large variations in the duration of pregnancy exist between individual mares and between individual pregnancies. Feto-maternal exchanges are first carried out by a choriovitelline tissue apposition, which then switches to an allantochorion around 25 days postovulation (dpo). The allantochorion develops close interactions with the entire endometrium through treelike structures called microcotyledons and enables nutritional exchanges as well as endocrine support for the pregnancy. In addition to these structures, a subpopulation of trophoblastic cells, unique to the horse, differentiates into transient, invasive trophoblast known as chorionic girdle. Chorionic girdle trophoblast gives rise to the endometrial cups which secrete equine chorionic gonadotropin (eCG) from 38 to around 120 days of pregnancy.

Microcotyledons branch out and grow throughout the entire gestation period, allowing the equine placenta to be a particularly adaptable organ. The maternal environment, however, such as nutrition, metabolism and pathologies, can alter placental development and in turn affect the development of the foal.

This review starts by briefly covering the normal development of placenta from fertilization, as well as the detailed structure of the definitive organ. This information is provided for the reader to be able to understand the following sections of the review. The second sections focus on how the maternal environment from early gestation (breed, parity, nutrition, assisted reproductive technologies) and pathology (early gestation pathologies, placental retention, hydrops, placentitis) affects placental gene expression and structure. The latter parts of the review mostly focus on late gestation because studies performed in early gestation remain scarce in equidae, and to our knowledge, none exist for mid-gestation. Because paternal contribution has been recently reviewed elsewhere (Wang et al. 2013, Dini et al. 2021), it is not considered here. For information concerning placental gene expression 
in normal pregnancies according to cell lineages or time of gestation, refer to the review from Loux et al. (2022).

\section{Morphological structure of the placenta throughout gestation}

\section{Before implantation}

The early stages of placental development have been thoroughly described (Allen \& Wilsher 2009). After fertilization, the embryo remains in the oviduct until 6-7 days post-ovulation (dpo), and at the blastocyst stage, trophectoderm cells secrete threonine-rich glycoproteins forming a capsule that persists intact until 20-21 dpo (Flood et al. 1982, Oriol et al. 1993, Albihn et al. 2003). The embryonic vesicle is mobile in the uterus until 16-17 dpo (around $22 \mathrm{~mm}$ diameter), when increased, myometrial tone prevents embryonic movements. After disintegration of the capsule, trophoblastic cells on the outer layer of the choriovitelline membrane become exposed to luminal epithelium and to endometrial gland secretions, allowing establishment of the first form of adherence of the conceptus to the endometrium and favouring histotrophic nutrition (van Niekerk \& Allen 1975).

The allantois originates from the posterior end of the embryonic gut and develops rapidly until it surrounds the embryo and fuses with the chorion to form the allantochorion that will become the main nutritional placenta. At $45 \mathrm{dpo}$, the allantois has completely replaced the yolk sac, which is incorporated into the umbilical cord that elongates from $40 \mathrm{dpo}$ (Ginther 1992). Meanwhile, organogenesis takes place and is complete at 35 dpo when the embryo becomes a fetus (van Niekerk \& Allen 1975).

\section{Implantation and the endometrial cups}

Invasive trophoblast cells differentiate from 25 to $35 \mathrm{dpo}$ from the chorionic tissue in the zone of apposition between allantois and yolk sac, forming a cellular girdle of about $0.5-1 \mathrm{~cm}$ width around the conceptus. The binucleate cells become hyperplastic, develop pseudopods allowing adherence to the endometrium and start migrating at 35-37 dpo along with the uterine glands into the endometrial stroma until 40-42 dpo. At this stage, these binucleated cells round off and enlarge to form the endometrial cups, i.e. concave horse-shoe shape structures at the endometrial surface (Allen \& Wilsher 2009). Maximal size and endocrine activity are reached at $70 \mathrm{dpo}$, followed by gradual degeneration from 80 dpo to complete loss at 100-120 dpo (Antczak et al. 2013). Endometrial cups secrete eCG hormone, possessing $\mathrm{FSH}$ - and $\mathrm{LH}$-like properties, that induce the development of secondary corpora lutea (Stewart et al. 1976). They persist until the allantochorion placenta is able to produce enough progestogens to maintain gestation (Ganjam et al. 1975).

\section{Development of the non-invasive placenta}

At $35-38 \mathrm{dpo}$, the allantois has vascularized more than $90 \%$ of the chorion. At $40 \mathrm{dpo}$, the trophoblast of the allantochorion begins to form microvilli enabling intimate contact with the endometrium (Allen et al. 1973). Fetal villi are formed over the whole surface of the conceptus, with the exception of uterine glands' apertures, where the trophoblast develops as a dome called areolae, consisting of columnar cells with high absorptive capacity (Allen \& Wilsher 2009). From 60 dpo, villi lengthen and branch intensively, with secondary branches appearing at $100 \mathrm{dpo}$, to result in microcotyledons around 120 dpo (Samuel et al. 1974) that continue to grow until term (Macdonald et al. 2000). Moreover, feto-maternal exchanges are enhanced as gestation progresses, with the distance between fetal vessels and trophoblast being reduced (fetal vessels have migrated into the trophoblast by $250 \mathrm{dpo}$ ) due to the merging of fetal vessels' basal lamina with that of the trophoblastic cells and the reduction of maternal epithelium thickness (Samuel et al. 1976).

\section{Definitive placentation}

In the horse, the definitive placenta is diffuse, with villi covering the whole surface of the uterus by term, and epitheliochorial, because allantochorion is simply affixed over the endometrium. Thus, between 5 and 6 cell layers separate maternal from fetal blood, depending on fetal vessel location. The definitive allantochorion is composed of (i) the allantois, consisting of an epithelium and a loose, highly vascularized, connective tissue (allantoic mesoderm) on the fetal side (Steven 1982) and (ii) the chorion, consisting of a tightly vascularized connective tissue (chorionic mesoderm) and a pseudostratified epithelium, (iii) the histotrophic trophoblast located along the areolae and specialized in the absorption of exocrine secretions of the uterine glands (histotrophic nutrition), and (iv) microcotyledons (haemotrophic trophoblast, connective tissue and fetal vessels) that insert into the endometrial microcaruncles (Fig. 1). Microcotyledons maximize the contact area between maternal and fetal epithelia for nutrient and waste exchange, which is further enhanced by the epithelial cells' membrane villi present on the microcotyledons, the haemotrophic trophoblast and on the endometrial epithelial cells (Samuel et al. 1976, Steven 1982) (Fig. 1B). At term, the placental structure was shown to differ between uterine regions (corresponding to the uterine body, the pregnant or the non-pregnant horn). In thoroughbred placentas, the placental villous height was shown to be reduced at the tip of the pregnant horn (but not the base) and allantoic vessels to be larger in the pregnant compared to the non-pregnant horn and the placental body (Oikawa et al. 1990). Moreover, in Brazilian Sport 


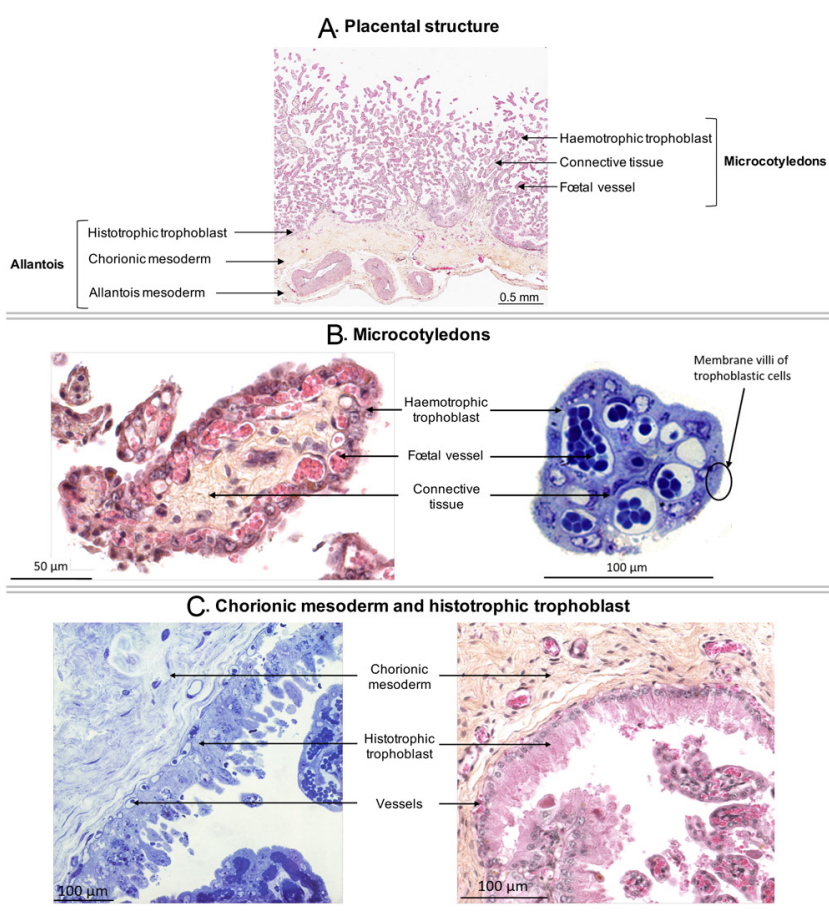

Figure 1 Structure of the equine placenta at term. (A) Haematoxylineosin-saffron staining of the whole placenta with both allantois and microcotyledons. Details on microcotyledonary (B) and allantoic (C) structures with haematoxylin-eosin-saffron staining or semi-thin sections with toluidin blue staining.

Horse and Mangalarga Paulista placentas, pregnant horn microcotyledons were shown to be less voluminous than that of non-pregnant horn and placental body, with less haemotrophic trophoblast, and the volume of the microcotyledonary vessels was increased in the placental body compared to both pregnant and nonpregnant horns (Meirelles et al. 2017).

In a recent stereological analysis of 43 placentas collected from French Anglo-Arabian mares, we confirmed the presence of important morphological differences between pregnant horn, non-pregnant horn and the zone of insertion of the umbilical cord (Robles, Chavatte-Palmer, Aïoun, Geeverding, Dubois, Wimel, personal communication) (Fig. 2, Material and Methods available in Supplementary data 1, see section on supplementary materials given at the end of this article). First, the volume of allantoic connective tissue (allantoic and chorionic mesoderms) was increased in the pregnant compared to the non-pregnant horn and umbilical cord insertion area, whereas the surface of the allantoic connective tissue was decreased in the nonpregnant compared to the pregnant horn and umbilical cord insertion area. Nevertheless, the microcotyledonary volume was increased in the non-pregnant compared to the pregnant horn and umbilical cord insertion area, due to an increased volume of haemotrophic trophoblast and microcotyledonary connective tissue, as well as of the microcotyledonary and haemotrophic trophoblast surfaces. These structural differences may result from increased stretching of the pregnant horn due to fetal volume. Moreover, the volume and surface of microcotyledonary vessels were increased at the site of umbilical cord insertion, compared to other locations. Finally, transmission and scanning electronic microscopy confirm the stereology results and show that membrane villi of the haemotrophic trophoblast cells appeared to be less developed in the pregnant compared to the nonpregnant horn (Fig. 3). Despite being diffuse and spreadover the whole uterus, the respective tissue proportions in the placental structure differ between sites. So far, differences in gene and protein expression according to placental location have not been confirmed. Therefore, especially for term placenta studies, it is important to describe where the placenta was sampled as differences in adaptation to maternal environment might exist between locations (pregnant horn, non-pregnant horn or placental body).

\section{Environmental and maternal factors that impact gene expression}

The summary of the effects of the maternal environment on placental gene expression is presented in Table 1.

\section{During early gestation: before implantation}

Asynchronous embryo transfer

Asynchronous embryo transfer corresponds to the transfer of an embryo in a more advanced (positive asynchrony) or delayed (negative asynchrony) uterine environment. Horse embryos tolerate 5 days or more negative asynchrony but are very sensitive to positive uterine asynchrony (Jacob et al. 2012). Moreover, negative asynchrony has been shown to delay embryo development in early gestation (Gibson et al. 2017), as demonstrated through both transcriptomic and candidate gene analyses (Table 1). Transcriptomic analysis showed underrepresentation of functional terms involved in embryo development (CNS, metanephros, retina layer formation) in 14-day-old bilaminar yolk-sacs (endoderm and trophectoderm) and of cell adhesion (cell adhesion, cell-matrix adhesion, regulation of cell shape, positive regulation of cell migration) as well as protein kinase activity and inflammatory response in 19-day-old trilaminar yolk-sacs (endoderm, trophectoderm and mesoderm) (Gibson et al. 2020). Finally, using a gene-candidate analysis, decreased expression of genes involved in placental function and fetal growth (maternal expression: H19, insulin-like growth factor 2 receptor $(I G F 2 R)$, Pleckstrin homology-like domain family $\mathrm{A}$ member 2 (PHLDA2); paternal expression: paternally expressed gene 3 protein(PEG3) and retrotransposonderived protein (PEG10)), DNA/RNA processing and 

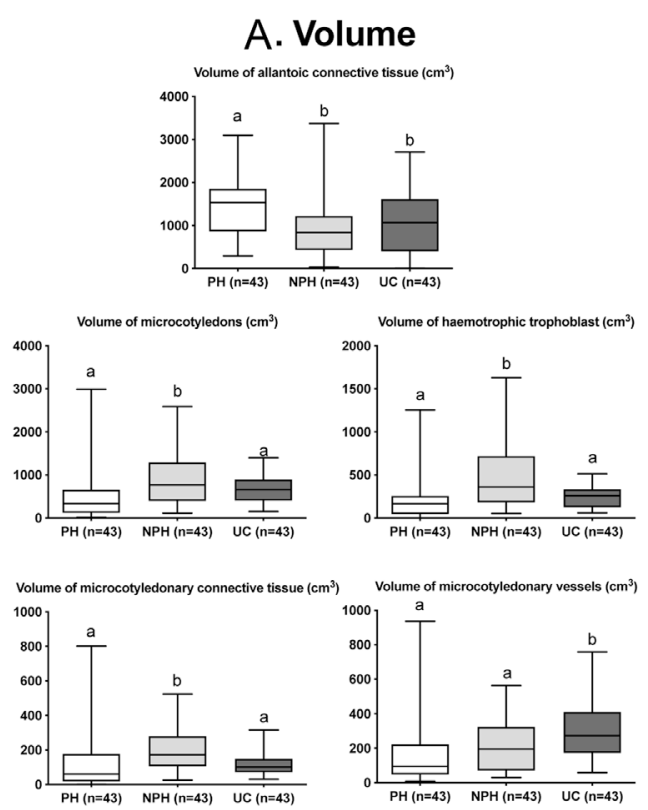

\section{B. Surface}
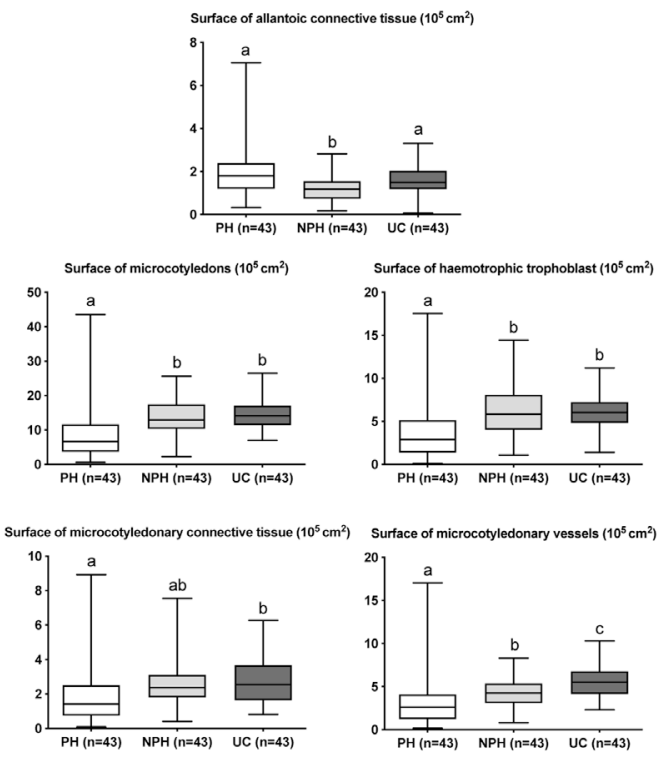

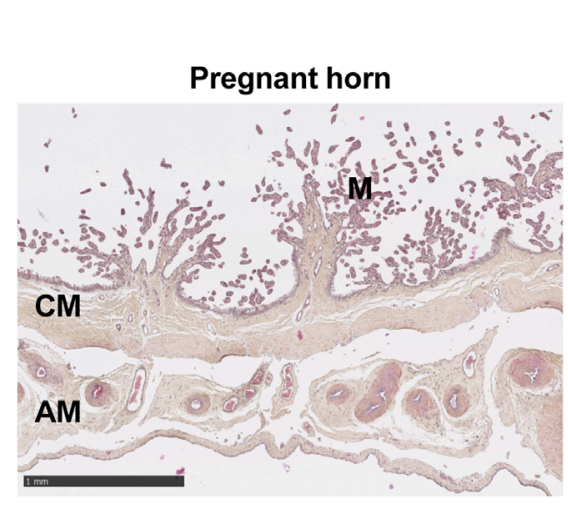

\section{Histology} Non-pregnant horn
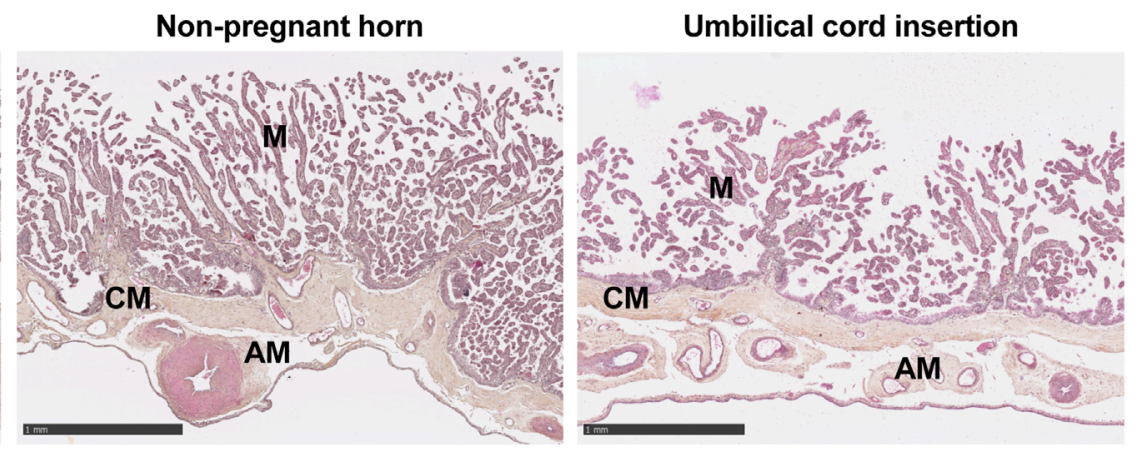

Figure 2 Differences in placental structure between pregnant horn $(\mathrm{PH}, n=43)$, non-pregnant horn $(\mathrm{NPH}, n=43)$ and umbilical cord insertion area (UC, $n=43$ ) at term. (A) Volume of allantoic and microcotyledonary components $\left(\mathrm{cm}^{3}\right)$. (B) Surface of allantoic and microcotyledonary components $\left(10^{5} \mathrm{~cm}^{2}\right)$. (C) Haematoxylin-eosin-saffron staining of term placentas sampled in the pregnant horn, the non-pregnant horn and above the umbilical cord insertion. AM, allantoic mesoderm; $\mathrm{CM}$, chorionic mesoderm; $\mathrm{M}$, microcotyledons; $\mathrm{AM}+\mathrm{CM}$, allantois connective tissue. Different superscript letters indicate a significant difference between placental regions $(P<0.05)$.

cell metabolism (insulin receptor (INSR)) and control of epigenetic regulations (histone acetyltransferase 1 (HAT1), DNA (cytosine-5)-methyltransferase 1 (DNMT1), DNA (cytosine-5)-methyltransferase 3A (DNMT3A), DNA (cytosine-5)-methyltransferase 3B (DNMT3B)) was observed in 19 dpo asynchronous compared to synchronous trilaminar yolk-sacs (Gibson et al. 2017). If more research is needed to understand the role of epigenetic modifications in embryo and placental development in the horse, these results show that DNA methylation and histone modifications are likely involved in the delayed development observed in asynchronous concepti. Moreover, the difference in expression of imprinted genes highlights their role as sensitive markers of early conceptus environment and placental development, as observed in other studies (Dini et al. 2021).

\section{Obesity}

Horses are grazing animals, so their body condition varies during the year, depending on the energy content of the pasture (Dawson \& Hone 2012). Horses are considered overweight when their body condition score exceeds 6 (1-9 scale) (Henneke et al. 1984) or 3.5 (0-5 scale) (Carroll \& Huntington 1988, Martin-Rosset et al. 2008) and obese when their body condition is higher than $7 / 9$ or $4 / 5$. Obesity has been shown to affect both placental structure and function in rodents, humans and non-human primates (Shook et al. 2020).

To our knowledge, only one study focussing on the effects of obesity on placental function has been performed in the horse (Sessions-Bresnahan et al. 2018). In light-breed mares, the effect of maternal obesity (defined as Body Condition Score (BCS) $>7$ and 
A. Pregnant horn (transmission)

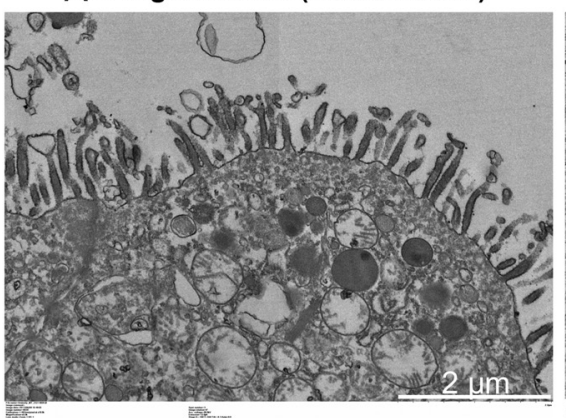

C. Pregnant horn (scanning)

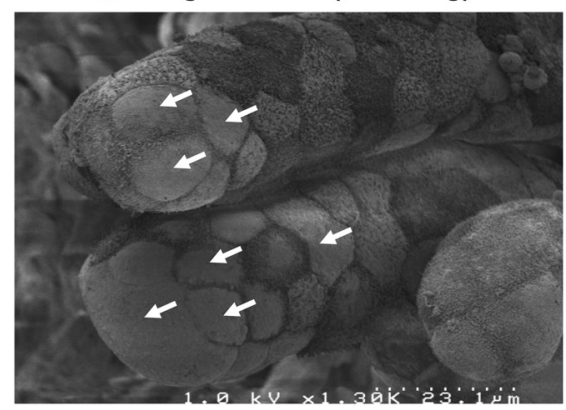

\section{B. Non-pregnant horn (transmission)}

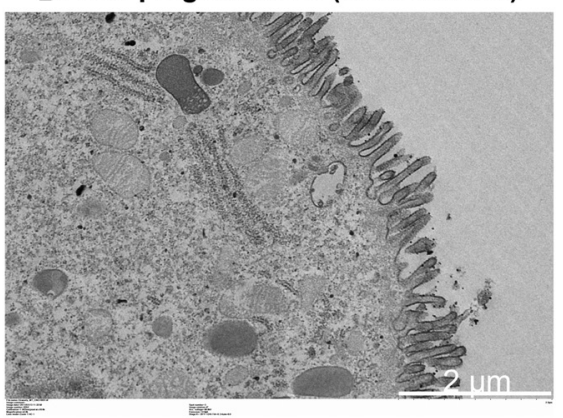

D. Non-pregnant horn (scanning)

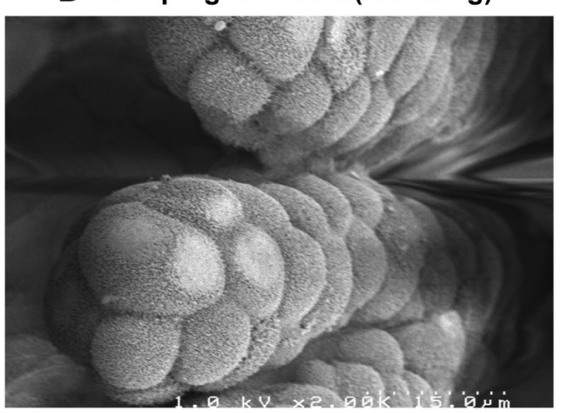

Figure 3 Transmission (A, B) and scanning (C, D) electron microscopy of haemotrophic trophoblast cells and placental villi (microcotyledons) in pregnant $(\mathrm{A}, \mathrm{C})$ and non-pregnant $(B, D)$ horns (Credits: Josiane Aioun and Audrey Geeverding). body fat $>10 \%$, increased leptin and insulin serum concentration, and insulin resistance) at ovulation was explored in the trophoblast at 16 dpo using a candidate gene approach (Table 1). The expression of genes involved in fatty acids transport was altered (increased expression of fatty acid synthase (FASN) and long-chain fatty acid transport protein 1 (SLC27A1), whereas the expression of cluster of differentiation 36 (CD36) was reduced). The expression of genes involved in oxidative and mitochondrial stress inhibition was also altered (increased expression of glutaredox-1 (GPX1) while thioredoxin-2 (TXN2) expression was reduced), as well as the expression of genes involved in inflammation (decreased expression of interleukin-6 signal transducer (IL6ST)) in obese compared to normal pregnancies (Sessions-Bresnahan et al. 2018). These results were associated with a tendency for a decrease in global DNA methylation in the embryonic discs of the obese group, which confirms that the alteration of maternal environment in obese mares can induce epigenetic modifications in the conceptus. Indeed, the expression of genes involved in fatty acids transport, inflammation, growth factor signalling and/or endoplasmic reticulum stress was altered in D8 embryos and D16 embryonic discs as well as in the endometrium collected from D16 contralateral uterine horns. Finally, obesity was associated with an inflamed uterine environment that altered conceptus gene expression until at least $16 \mathrm{dpo}$. Effects of obesity on placental function later during pregnancy and at term remain, to our knowledge, unexplored in the equine species. Nevertheless, maternal obesity throughout gestation was shown to promote chronic inflammation and affects glucose metabolism, as well as osteoarticular development in offspring until at least 18 months of age (Robles et al. 2018a).

\section{Omega-3 fatty acids supplementation}

Omega-3 fatty acids are essential fatty acids known to have immunomodulatory and anti-inflammatory effects in horses (Warren \& Vineyard 2013). Fresh grass is rich in omega-3 fatty acids (Dewhurst et al. 2001). Cereals, conversely, are rich in omega- 6 fatty acids, known for their pro-inflammatory effects (Ryan et al. 2007). Modern diets of horses, which are mainly composed of cereals and conserved forages, are far richer in omega- 6 than pasture, which means that supplementation of horse feeds with omega-3 sources such as linseed, for instance, may have positive effects on horse health. Because of their immunomodulatory effects, and also their roles in neurodevelopment and metabolism as shown in other species (Buddington et al. 2018, Madore et al. 2020, Shrestha et al. 2020), these fatty acids may affect embryo implantation as well as placental and fetal development.

Overweight light breed mares (mean BCS of 7/9) were supplemented with an algae-derived product, rich in omega-3 fatty acids (especially in docosahexaenoic (DHA) and eicosapentaenoic (EPA) acids), from 45 days before ovulation (Jacobs et al. 2018). Mares supplemented with omega-3 had increased incorporation of DHA and total omega- 3 fatty acids in the endometrium compared to control mares. Moreover, gene expression of markers of trophectoderm differentiation (Trans-acting T-cell-specific transcription factor (GATA3), transcription factor AP-2 alpha 
Table 1 Summary of the effects of maternal environment on placental gene expression. Differences are expressed compared to control. RT-qPCR was used to quantify gene expression in these studies.

\begin{tabular}{|c|c|c|c|}
\hline Maternal factor & Tissue & Gene category and expression & Source \\
\hline \multicolumn{4}{|l|}{ Early gestation } \\
\hline \multirow[t]{3}{*}{ Obesity } & D16 trophectoderm & $\begin{array}{l}\text { Fatty acid transport: } \uparrow F A S N ; \uparrow S L C 27 A 1 ; \\
\downarrow C D 36\end{array}$ & Sessions-Bresnahan et al. (2018) \\
\hline & & $\begin{array}{l}\text { Oxidative and mitochondrial stress: } \\
\uparrow G P X 1 ; \uparrow T X N 2\end{array}$ & \\
\hline & & Inflammation: $\downarrow$ IL6ST & \\
\hline \multirow[t]{2}{*}{ Omega-3 } & D12.5 conceptus & $\begin{array}{l}\text { Trophectoderm differentiation: } \uparrow \text { GATA3; } \\
\uparrow T F A P 2 A ; \uparrow E L F 3\end{array}$ & Jacobs et al. (2018) \\
\hline & & $\begin{array}{l}\text { Primitive endoderm differentiation: } \\
\uparrow \text { GATA4; } \uparrow \text { GATA6 }\end{array}$ & \\
\hline \multirow[t]{3}{*}{ Asynchronous embryo transfer } & D19 trilaminar yolk-sacs & $\begin{array}{l}\text { Placental function and fetal growth: } \downarrow \text { H19; } \\
\downarrow \text { IGFR2; } 2 \text { PHLDA2; } \downarrow \text { PEG3; } \downarrow \text { PEG10 }\end{array}$ & Gibson et al. (2017) \\
\hline & & $\begin{array}{l}\text { DNA/RNA processing and cell } \\
\text { metabolism: } \downarrow \text { INSR }\end{array}$ & \\
\hline & & $\begin{array}{l}\text { Control of epigenetic regulations: } \downarrow \text { HAT1; } \\
\downarrow \text { DNMT1; } \downarrow \text { DNMT3; } \downarrow \text { DNMT3B }\end{array}$ & \\
\hline \multicolumn{4}{|l|}{ At term } \\
\hline \multirow{3}{*}{$\begin{array}{l}\text { Breed: pony vs draft and } \\
\text { Saddlebred }\end{array}$} & Term placenta & Growth and development: $\downarrow$ IGF2; $\downarrow$ IGF2R & Robles et al. (2018a) \\
\hline & & $\begin{array}{l}\text { Nutrient transfer: } \downarrow \text { SLC2A1; } \downarrow \text { SLC38A2; } \\
\downarrow \text { LPL }\end{array}$ & \\
\hline & & Vascularization: $\downarrow$ FLT1; $\downarrow$ KDR & \\
\hline \multirow[t]{2}{*}{ Breed: Saddlebred vs draft } & Term placenta & Growth and development: $\downarrow$ IGF2 & \\
\hline & & Vascularization: $\downarrow$ KDR & \\
\hline \multirow[t]{2}{*}{ Primiparity } & Term placenta & $\begin{array}{l}\text { Growth and development: } \downarrow \text { IGF1R; } \\
\downarrow \text { TGF } \beta 1 ; \downarrow \text { EGFR }\end{array}$ & Robles et al. (2018b) \\
\hline & & Vascularization: $\downarrow$ VEGF $\alpha$ & \\
\hline Commercial ET and ICSI & Term placenta & No difference & Valenzuela et al. (2018) \\
\hline $\begin{array}{l}\text { Pony embryos transferred into } \\
\text { draft mares }\end{array}$ & Term placenta & Nutrient transfer: $\uparrow S L C 38 \mathrm{~A} 1$ & Robles et al. (2018e) \\
\hline \multirow[t]{2}{*}{$\begin{array}{l}\text { Saddlebred embryos transferred } \\
\text { into pony mares }\end{array}$} & Term placenta & $\begin{array}{l}\text { Growth and development: } \downarrow \text { H19; } \downarrow \text { IGF2; } \\
\text { } \text { IGF1R; } \downarrow \text { IGF2R }\end{array}$ & \\
\hline & & $\begin{array}{l}\text { Nutrient transfer: } \downarrow \text { SLC2A1; } \downarrow \text { SLC38A2; } \\
\downarrow \text { LPL }\end{array}$ & \\
\hline L-arginine supplementation & Term placenta & Nutrient transfer: $\downarrow$ SLC2A1; $\downarrow$ CD36 & Robles et al. (2019) \\
\hline
\end{tabular}

(TFAP2A) and E74-like ETS transcription factor 3 (ELF3)) as well as primitive endoderm differentiation (GATAbinding protein 4 (GATA4) and GATA-binding protein 6 (GATA6)) was increased in D12.5 conceptuses from omega-3-supplemented mares compared to control (Table 1) (Jacobs et al. 2018).

Thus, omega-3 fatty acids supplementation could help improve early placental development, at least in overweight animals, but these effects need to be confirmed in other studies to determine if they translate to changes in protein expression and consequently wider benefits for the developing fetus. Effects of omega-3 supplementation on late-pregnancy and term placental function and structure, as well as on development of the offspring, remain to be investigated.

\section{During late gestation: last third of gestation}

\section{Effect of breed}

The different breeds of horses have been either selected by humans to fulfil specialized activities, such as racing (thoroughbred), sport (warmblood horses) or traction (draft horses) for example. Some have been adapted to harsh environments, such as severe winter (ponies) or dry and hot environments (Arabians and Iberian horses). From these specificities, different sizes and formats, as well as metabolic specificities, were derived. For instance, ponies and Iberian horses have been shown to be more insulin resistant than Saddlebred horses (Bamford et al. 2014, Peugnet et al. 2014).

In alignment with adult size, ponies are born lighter than thoroughbred and French Anglo-Arabian horses that are born lighter than draft horses. These differences between breeds are correlated with placental surface area (Allen et al. 2002, Robles et al. 2018b) and associated with variation in placental function. The placenta of ponies appears to be the most efficient, as the birthweight to placental surface area ratio is increased compared to French Anglo-Arabians and draft horses. Moreover, the surface density (surface per volume unit, $\mu \mathrm{m}^{-1}$ ) and volume fraction (volume per volume unit, \%) of microcotyledonary vessels are increased in pony compared to French Anglo-Arabian placentas (Robles et al. 2018b). Surface density and surface of microcotyledons, however, were shown to 
be reduced in pony compared to thoroughbred term placentas (Allen et al. 2002) (Fig. 4A). This could mean that despite a decreased placental exchange surface in ponies, there was a placental vascular compensation that could explain the increased placental efficiency observed in the small breed compared to bigger horses. Moreover, the expression of genes involved in growth and development is reduced in pony compared to Saddlebred and draft (IGF2 and its receptor IGF2R) and in Saddlebred compared to draft placentas (IGF2) (Table 1). The expression of genes involved in nutrient transfer is reduced in pony compared to Saddlebred placentas (solute carrier family 2, facilitated glucose transporter member 1 (SLC2A1), sodium-coupled neutral amino acid transporter 2 (SLC38A2), lipoprotein lipase $(L P L))$. Finally, genes involved in vascularization are expressed less in pony and Saddlebreds compared to draft placentas (Fms related tyrosine kinase 1 ( $F L T 1$ ), kinase insert domain receptor $(K D R)$ ) (Robles et al. 2018b). These latter results indicate that genes directly or indirectly involved in fetal growth are less expressed in pony placentas compared to larger breeds, which is in agreement with the smaller size of the breed.

Altogether, these results highlight the fact that there are differences between breeds in terms of placental structure and function, at least at term, and that results observed in one breed may not be reproducible in another one. Uterine size and maternal metabolism thus affect feto-placental development and should be considered when designing a study. To our knowledge, early pregnancy placental development has not been compared between breeds.

\section{Effect of maternal parity and age}

In the equine species, maternal parity has been shown to have strong effects on birth weight, growth and metabolism of foals. Primiparous mares produce lighter and smaller foals until at least 18 months of age (Wilsher \& Allen 2003, Elliott et al. 2009, Meirelles et al. 2017, Robles et al. 2018b,c). In addition, the maturation of metabolic and male reproductive functions appears to be delayed in these foals (Robles et al. 2018c). As a result, foals born to primiparous dams might be slightly less performant than foals born to multiparous mares, at least in racing (Barron 1995) and show jumping (Palmer et al. 2018).

Indeed, first pregnancies are different from subsequent ones. The uterine artery diameter and blood flow volume are reduced in mares that foaled two foals or less compared to mares with a higher parity (Klewitz et al. 2015). In terms of placental structure, haemotrophic (microcotyledons) (Wilsher \& Allen 2003, Meirelles et al. 2017) and histotrophic (Robles et al. 2018c) exchange surfaces are reduced in term placentas of primiparous compared to multiparous dams (Fig. 4B). Finally, the expression of genes involved in growth and development, such as IGF1R, transforming growth factor beta 1 (TCF $\beta 1)$ and epidermal growth factor
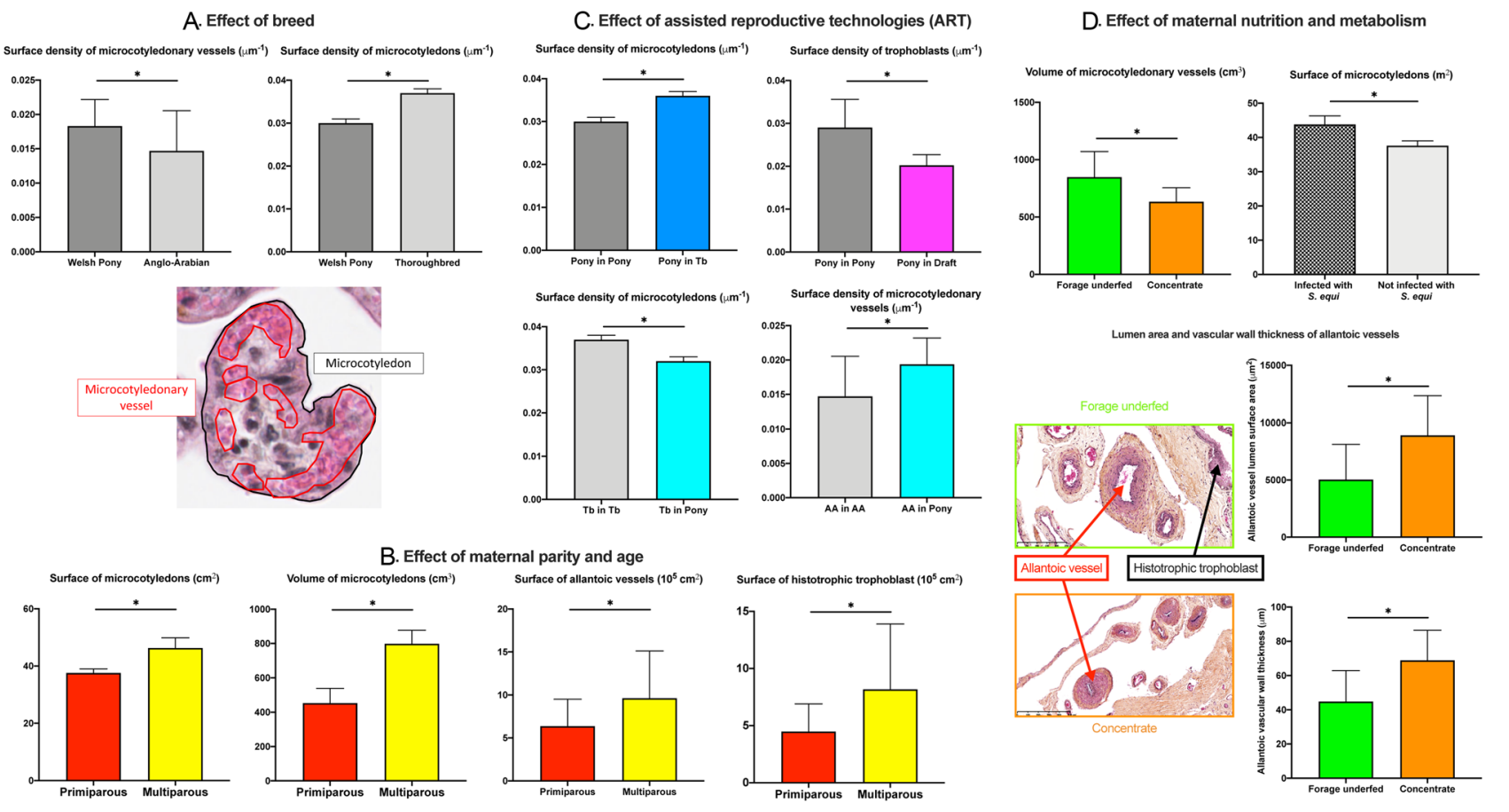

Figure 4 Differences in placental structure as measured using the stereology method according to breed (A), parity (B), embryo transfer between breeds (C) and maternal nutrition and metabolism (D). Results were compiled from (A) Robles et al. (2018b), (B) Robles et al. (2018c, 2019), (C) Allen et al. (2002), Robles et al. (2018d), and (D) Robles et al. (2018e), Wilsher and Allen (2006). 
receptor $(E G F R)$ and in vascularization, such as vascular endothelial growth factor $A(V E G F \alpha)$, is reduced in primiparous compared to multiparous term placentas (Robles et al. 2018c, 2019) (Table 1). Conversely, the expression of genes involved in protein metabolism and transport (arginase 2 (ARG2), ornithine decarboxylase 1 (ODC1) and high-affinity cationic amino acid transporter $1(S L C 7 A 1))$ is increased in primiparous compared to multiparous term placentas, which could reduce the feto-maternal amino acid transfer capacity in primiparous placentas (Robles et al. 2019). These results are consistent with the effects of primiparity observed on uterine blood flow (Klewitz et al. 2015) and placental morphometry at birth (Wilsher \& Allen 2003, Elliott et al. 2009, Meirelles et al. 2017, Robles et al. 2018c).

Effects of decreased placental development and function may be enhanced not only by a decreased uterine ability to expand, as measured through a decreased placental gross surface at birth in primiparous pregnancies (Wilsher \& Allen 2003), but also by an inability of primiparous dams to adapt their metabolism to pregnancy (Robles et al. 2019). Generally, in late gestation, pregnant mares become less glucose tolerant and produce less insulin in response to an increased glycaemia, in order to maximize the placental transfer of glucose to the fetus (Fowden et al. 1984). Higher postprandial insulin secretion was observed in primiparous vs multiparous mares, however, and it was hypothesized that these elevated insulin concentrations could reduce glucose availability for transfer to the fetus (Robles et al. 2019). Finally, a reduced global DNA methylation was observed in placentas of primiparous compared to multiparous dams, suggesting that epigenetic modifications may also play a role in parityrelated variations in placental development (Robles et al. 2019).

Maternal parity is positively correlated to maternal age, and as a result, maiden mares are also often young mares. Maternal age has also been shown to affect the weight of placenta and foal at birth as young $(<9$ years old) and old ( $>16$ years old) mares produce lighter foals than mares aged between 9 and 16 years (Wilsher \& Allen

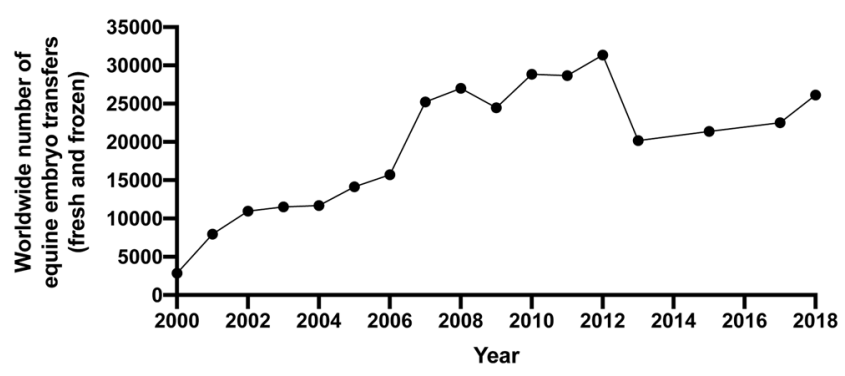

Figure 5 Worldwide number of equine embryo transfers between 2000 and 2018 (derived from Data Retrieval Committee Reports of the International Embryo Technology Society (International Embryo Technology Society (IETS)).
2003, Elliott et al. 2009). These observations have been correlated to placental structure as microcotyledonary surface density decreases as maternal age increases (Wilsher \& Allen 2003). Moreover, together with mare ageing, the endometrium undergoes fibrotic degenerative changes that can lead to endometriosis and therefore affect placental development. To our knowledge, the effect of maternal age on placental gene expression has not been studied. Effects of both age and parity on placental and embryo/fetal development remain to be investigated.

\section{Effect of assisted reproductive technologies (ART)}

ART are increasingly used to produce foals from high genetic value mares (Fig. 5) in order to increase the number of foals born to a mare each year. This enables the production of foals while the mare continues to compete and produce foals from infertile mares. To our knowledge, apart from equine pregnancies following nuclear transfer where placental abnormalities have been described (Johnson et al. 2010, Pozor et al. 2016), reports of developmental or pregnancy issues following ART in the horse are non-existent, despite the fact that ART have been shown to be associated with developmental and pregnancy issues in human and other animals (Duranthon \& Chavatte-Palmer 2018). In the horse, commercial ART (embryo transfer (ET) and intracytoplasmic sperm injection (ICSI)) were shown to have neither effect on the placental expression of 19 genes involved in growth and development, vascularization and nutrient transfer nor on placental morphology (Valenzuela et al. 2018).

When embryo transfers are performed between breeds of different size, however, effects on placental structure and function are observed. Pony embryos transferred to thoroughbred or draft mares were born heavier, with a heavier and larger placenta than pony embryos carried by pony mares (Allen et al. 2002, Robles et al. 2018d). These differences in feto-placental biometry were associated with different placental structure alterations, depending on whether the embryo was transferred into a thoroughbred or a draft mare (Fig. 4C):

- Thoroughbred: the surface density and surface of microcotyledons were increased in transferred compared to pony-in-pony placentas (Allen et al. 2002).

Draft: the surface density of trophoblastic tissues (haemotrophic and histotrophic trophoblasts) was decreased in transferred compared to pony-in-pony placentas (Robles et al. 2018d).

The gene expression of sodium-coupled neutral amino acid transporter 1 (SLC38A1), involved in amino acid transfer, was increased in term placentas of pony embryos transferred to draft mares. Despite modifications in placental structure, the placental 
expression of genes involved in growth and development or vascularization did not differ between both groups (Robles et al. 2018d).

In contrast, French Anglo-Arabian/Thoroughbred embryos transferred into pony mares were born lighter, with a lighter placenta than that of Saddlebred-inSaddlebred foals (Allen et al. 2002, Robles et al. 2018d). These differences were associated to alterations in placental structure that differed depending on whether the embryo was transferred into a Thoroughbred or a French Anglo-Arabian mare (Fig. 4C):

- Thoroughbred: The surface density and surface of microcotyledons were decreased in transferred compared to control placentas (Allen et al. 2002).

- French Anglo-Arabian: the surface density and volume fraction of microcotyledonary vessels were increased in placentas of transferred compared to control embryos (Robles et al. 2018d).

Moreover, the expression of genes involved in growth and development (H19, IGF2 IGF2R and IGF1R) and nutrient transfer (SLC2A1, SLC38A2 and $L P L$ ) was decreased in placentas of transferred compared to control embryos (Robles et al. 2018d). These results may result from vascular placental adaptations in order to ensure nutrient transfers to the fetus despite the limitation imposed by uterine size.

These results coincided, however, with differences in methodology (differences in parity, body condition score, feeding and housing between groups) at least in the Anglo-Arabian study (Peugnet et al. 2014). These differences therefore need to be confirmed and further studied.

\section{Effect of maternal nutrition and metabolism}

Effects of starch and insulin resistance Horses are monogastric herbivorous animals that have evolved to eat grass all day (Martin-Rosset et al. 1978). In modern practice, horses are housed in boxes or in small pastures and are often fed conserved forages that do not have the quality of fresh grass. To meet their needs in energy and proteins, they are also fed with concentrated feeds, composed of cereals, rich in starch and sugar. Supplementation with starch-rich concentrates has been associated with metabolic alterations, such as insulin resistance, in both pregnant (Peugnet et al. 2015) and non-pregnant horses (Bamford et al. 2016). Moreover, these diets are associated with increased risks of developing osteochondrosis lesions in growing foals (Vander Heyden et al. 2013, Peugnet et al. 2015), as well as decreased colostrum quality at birth (Caure \& Lebreton 2004, Thorson et al. 2010, Robles 2017).

An increase in allantoic arteriole vascular wall thickness (Fig. 4D) and a decrease in microcotyledonary vessels volume have been observed in term placentas of mares fed with cereals (flattened barley, $3.5 \mathrm{~kg} /$ day, last 4.5 months of gestation) compared to mares fed with forages only (Robles et al. 2018e). These vascular alterations were also linked to modifications in the enrichment of gene sets involved in placental vascularization, inflammation, coagulation and collagen production in mares fed with concentrates (Robles et al. 2018e). Placental inflammation may therefore also be involved in the mediation of the effects of cereal feeding in broodmares on the development of osteoarticular diseases in foals.

Insulin resistance is also associated with chronic inflammation. Moreover, increased vascular wall thickness (vascular fibrosis) of allantoic arterioles as well as fibrosis in microcotyledons were reported in term placentas from laminitic broodmares (Pazinato et al. 2017).

Effects of maternal undernutrition Maternal moderate undernutrition neither seem to affect foals birthweight nor placental measurements and efficiency (Henneke et al. 1984, Peugnet et al. 2015, Robles et al. 2018e). Despite the lack of effect on placental gross morphology at term, placentas from slightly underfed mares fed with forage only (very poor in soluble carbohydrates but rich in fibres) had an enrichment in gene sets involved in amino acids, folate and anions transport, and amino acids, fatty acids, cholesterol and folate catabolism compared to mares fed at $100 \%$ of their needs but with concentrates in addition to forage (Robles et al. 2018e). This observation indicates that placental metabolism is able to adapt to the source of energy. Placental cells seem to rely primarily on the amino acids and fatty acids catabolism to produce energy when the mare is underfed but with forage only. These placental adaptations could then partly explain why moderate undernutrition did not affect the weight of foals at birth but affected their long-term development (Peugnet et al. 2015, Robles et al. 2017).

Effects of L-arginine supplementation L-arginine is an essential amino acid during pregnancy and growth in the horse. Compared to other species, the milk of mares is particularly rich in L-arginine, which indicates that L-arginine needs are high in growing fetuses and foals. In the horse, L-arginine supplementation during pregnancy (100 g/day, for 21 days before foaling) has been shown to increase uterine artery blood flow in the non-pregnant horn and to decrease the gestational length without affecting, however, foal and placental biometry at birth (Mortensen et al. 2011). In this study, mares' parity was not provided, although the effects of L-arginine supplementation may differ between primiparous and multiparous dams. Indeed, L-arginine supplementation (100 g/day during the last 4.5 months of gestation) was 
shown to affect the metabolism of primiparous but not multiparous mares, leading to an increased metabolic adaptation to pregnancy in supplemented compared to control primiparous mares (Robles et al. 2019). These modifications of maternal environment may have also affected placental function as expression of SLC2A1 and $C D 36$ was increased in arginine-supplemented primiparous placentas, compared to placentas from control primiparous mares (Robles et al. 2019).

\section{Pathologies that impact on placental gene expression}

\section{Early pregnancy}

Pathologies of pregnancy can lead to pregnancy failure at any stage between fertilization and parturition. Early pregnancy loss $(E P L)$ is the most common occurrence in the mare and includes both embryo loss prior to clinical detection and 6-12\% clinically confirmed pregnancies that are lost within 2 months of conception (Bosh et al. 2009, Rose et al. 2018). For many years, the characterization of gene expression in the placentae of failed early pregnancies (EPL) was hampered by a lack of materials and methodologies. This has now been partly overcome (Rose et al. 2016), although data indicated that the quality of the placental tissue was, in the majority of cases, only suitable for genomic studies and to some degree histological analysis. Applying these methodologies to develop a large biobank of EPL tissue, Shilton et al. (2020) reported aneuploidy in the allantochorion or chorion of $22 \%$ of EPLs, suggesting this condition is a common reason for pregnancy to fail before 65 days. Aneuploidy is a genetic imbalance that arises due to loss or gain of a whole chromosome. Of $55 \mathrm{EPL}$ assessed, trisomy was identified in $16.3 \%$ and monosomy in $5.4 \%$ of placental membranes (Shilton et al. 2020) with the latter almost certainly lethal with no surviving monosomies reported. The phenotype of mammalian trisomies is more varied; some are associated with miscarriage alone, while others, like the well-reported human trisomies 13, 18, 21, can result in the birth of a live infant. Preliminary data in the mare suggest that the size of the chromosome may dictate whether the trisomy is embryonic lethal or can produce a greater spectrum of phenotypes (Shilton et al. 2020). It is plausible that such copy number changes disrupt gene expression in the placenta, although this needs to be confirmed experimentally.

A second pathology of early pregnancy is endometritis that is associated with approximately $5-10 \%$ of EPL cases in well-managed mares (Ricketts 2003, Rose et al. 2018). While changes in endometrial gene expression in response to the presence of endometritis have been reviewed (Morris et al. 2020), the genes and signalling pathways within the placental membranes following infection have not been investigated which is in stark contrast to the extensive work on placentitis in late gestation, discussed below. Clearly, there is still much to do to better understand the key genes and signals in the early placenta that can lead to EPL. The recent description of defects in the brain and cardiovascular systems of equine embryos/fetuses from clinical cases of EPL (Kahler et al. 2021), along with mounting data linking such defects to placental aberrations in rodent models (Woods et al. 2018), certainly suggests this is an avenue worth pursuing.

\section{Placentitis}

Placental infection (placentitis) is one of the major causes of late-term abortion in mares, responsible for the loss of $1-5 \%$ of all pregnancies (Lyle 2014). Despite its prevalence, most published gene-related research has focused on experimental models rather than clinical cases. This has the advantage of facilitated sampling and a better-defined timeline; however, the course of disease can differ significantly, with a more acute, severe reaction seen in response to induced placentitis. As an inflammatory disease, much of the early work focused on the pro-inflammatory cytokine response, identifying an early upregulation of interleukin 6 (IL-6) and interleukin 8 (IL-8) at the cervical star (LeBlanc et al. 2002) and interleukin 18 (IL-18), interleukin 15 (IL-15) and interferon $\gamma(I N F \gamma)$ in the placental body (Lyle et al. 2009). The balance of cytokines has since been revealed to be more complex, with the maternal response being primarily pro-inflammatory, while modulated by the fetus through production of interleukin 10 (IL-10) and IL-6 (Fedorka et al. 2019). The myometrial and cervical response to placentitis are quite similar to the allantochorion, with a similar upregulation of both proinflammatory and modulatory cytokines (interleukin $1 \beta) I L-1 \beta$ and $I L-8$ in both, IL-6, tumor necrosis factor $\alpha$ (TNF $\alpha$ ) and interleukin 10 (IL-10) in cervix) (El-Sheikh Ali et al. 2019, Fernandes et al. 2020).

Use of next-generation sequencing (NGS) identified toll-like receptor signalling as an important pathway for the myometrial immune response, as well as 8 transcripts which were placentitis specific (matrix metallopeptidase 1 (MMP1), matrix metallopeptidase 8 (MMP8), S100 calcium-binding protein A8 (S100A8), S100 calciumbinding protein A9 (S100A9), peptidase inhibitor 3 $(P I 3)$, apolipoprotein B mRNA-editing enzyme-catalytic polypeptide-like $3 Z 1 \mathrm{~b}(A P O B E C 3 Z 1 B)$, resistin (RETN) and $\mathrm{C}-\mathrm{X}-\mathrm{C}$ motif chemokine ligand 2 (CXCL2)). These genes are all involved in the regulation of immune and inflammatory processes and may be involved in placentitis-induced myometrial activation and initiation of preterm birth. This work also proposed signal transducer and activator of transcription 1 (STAT1) as an up-stream regulator for placentitis, while STAT3 may regulate transcriptional changes in the preterm period (El-Sheikh Ali et al. 2020a). 
The endocrine response to placentitis is wellcharacterized; however, the underlying gene-level changes have only recently come under scrutiny. Expression of steroid 5 alpha-reductase 1 (SRD5A1) and Aldo-keto reductase family 1 member C23 (AKR1C23), key progesterone-metabolizing enzymes, was reduced in the allantochorion, corresponding to a decrease in 5a-reduced progestogens in the same tissues. Likewise, aromatase (CYP19A1) expression trended down in the allantochorion, a trend accompanied by lower estrone and oestrogen receptor (ESR1) concentrations (El-Sheikh Ali et al. 2020b). A tissue-specific response is evident, as ESR 1 is instead upregulated in cervical stroma during placentitis, as are prostaglandin synthases prostaglandin E synthase (PTGES) and prostaglandin-endoperoxide synthase 2 (PTGS2) (Fernandes et al. 2020). These recent studies showcase the multi-faceted nature of placentitis, including robust maternal and fetal immune responses far beyond the placenta, with each tissue exhibiting its own unique response to placentitis.

\section{Hydrops}

Hydrops occurs when excess fetal fluid builds up during gestation. It can affect either the allantoic (hydroallantois) or amniotic (hydroamnios) fluid cavity. Although little information exists on the aetiology of hydrops, hydroallantois appears to be associated with impaired placental angiogenesis. Not only do hydroallantoic placentae exhibit reduced capillary density but also gene expression changes are indicative of altered angiogenesis and hypoxic changes. Specifically, hypoxia-induced gene hypoxia-inducible factor 1-alpha (HIF1A) is upregulated, as is VEGF, a known inducer of vascular permeability. Meanwhile, VEGF receptors VEGFR1 and VEGFR2 are downregulated. Evidence for the involvement of oestrogen dysfunction also exists, as both CYP19A1 and oestrogen receptors ESR1 and ESR2 are downregulated (Dini et al. 2020). Although preliminary, this work sheds light on underlying gene dysregulation associated with hydroallantois, as well as highlighting potential consequences for insufficient angiogenesis during placentation.

\section{Placental retention}

Placental retention is defined as a failure to expel fetal membranes within $3 \mathrm{~h}$ of delivery. This condition is common in the horse, especially in draft horse breeds, but its aetiology is still poorly understood. Placental retention causes endometritis and can lead to lifethreatening diseases such as endotoxemia, laminitis and septicaemia. Histologically, at term, placental retention has been associated with fibrosis in the microcotyledons, overdeveloped stromal connective tissue in the nonpregnant horn (retained horn), oversized histotrophic epithelium and sparser and shorter villi (microcotyledons) in draft mares' placentas (Rapacz et al. 2012, Rapacz-
Leonard et al. 2015a). These structural alterations were associated with a higher apoptotic index in both haemotrophic and histotrophic trophoblasts, as well as in both luminal and glandular endometrial epitheliums (Paździor et al. 2012). Increased gene and protein expression of matrix metalloproteinase-2 (MMP-2) were also observed, together with increased gene expression of matrix metalloproteinase-9 (MMP-9) and decreased expression of tissue inhibitor of metalloproteinases 2 (TIMP-2) in retained compared to control allantochorions (Rapacz-Leonard et al. 2015b). Moreover, MMP-2 activity was reduced in retained compared to control placentas. Gene expression of $I L-1 \beta$ and $I L-6$ (as well as protein expression of IL-6) was also increased in retained allantochorions (Jaworska \& Janowski 2019). Gene expression of prostaglandin endoperoxide synthase-2 (PTCS2), involved in prostaglandin production, was however decreased in retained placenta which could contribute to the observed imbalance in inflammatory processes and tissue remodelling in this pathology (Rapacz-Leonard et al. 2020). Finally, protein expression of oxytocin receptors (OXTR) was greatly reduced in retained placentas in case of secondary atony, but this difference was not observed in retained allantochorion without secondary atony (Rapacz-Leonard et al. 2015b, 2020). From these results, it can be concluded that abnormal placental development results from abnormal epithelial regeneration, as well as abnormal extracellular matrix remodelling and inflammatory signalling.

\section{Streptococcus equi infection}

Streptococcus equi, or strangles, is a highly contagious disease observed worldwide in horses (Mitchell et al. 2021). The condition is characterized by the development of abscesses in the head and neck lymph nodes, pharyngitis, as well as fever and lethargy (Boyle et al. 2018). In one study, young (3-4 years old) primiparous mares were infected with $S$. equi between 14 and 161 days of gestation. No antibiotics were administrated. In addition to other symptoms (such as fever, nasal discharges, inflamed and swollen lymph nodes and depression), this infection led to a severe undernutrition for a median of 3 weeks. Infected mares had a decreased placental microcotyledonary surface (Fig. 4D), leading to a decreased birth weight of their foals. Placental function, however, was not investigated in this study (Wilsher \& Allen 2006).

\section{Conclusion and final remarks}

Despite all the new information that has been provided during the last decade, a lot of unknowns remain concerning factors affecting placental development in horses. So far, apart from one study that performed RNA sequencing (RNAseq) to analyse differences in gene expression between two nutritional conditions, all 
reports comparing gene expression in equine placenta in response to environment at large used a RT-qPCR candidate gene approach, thus greatly limiting the possibility to uncover unexpected mechanisms that could be highlighted by high throughput approaches. Even though RT-qPCR approaches provide valuable information as gene expression is compared between equal total RNA concentrations per sample, variations in placental size and in gene expression between placental zones may affect total placenta expression and the conclusions that can be drawn from results. Moreover, there might be a change in cell composition between samples that is not controllable in the field but could be corrected with the use of trophoblastic cells marker genes for example (see Loux et al. 2022 for more information on gene expression between cell lines). It is thus always important to combine gene expression approaches, whether limited to a few candidates or unbiased through high throughput strategies, with physiological and structural observations.

In any case, RNseq approaches are essential because they provide an unbiased analysis necessary for understanding (i) the pathogenesis of placental disease in order to help the design of therapeutic treatments and (ii) the processes leading to the programming of foal's health in order to elaborate strategies to maximize health, welfare, performance and longevity in horses. Additionally, more refined methodologies such as single-cell RNAseq would be useful to determine the respective contribution of different cell lines in placental gene expression.

\section{Supplementary materials}

This is linked to the online version of the paper at https://doi. org/10.1530/REP-21-0116.

\section{Declaration of interest}

The authors declare that there is no conflict of interest that could be perceived as prejudicing the impartiality of this review.

\section{Funding}

This work did not receive any specific grant from any funding agency in the public, commercial, or not-for-profit sector.

\section{References}

Albihn A, Waelchli RO, Samper J, Oriol JG, Croy BA \& Betteridge KJ 2003 Production of capsular material by equine trophoblast transplanted into immunodeficient mice. Reproduction 125 855-863. (https://doi. org/10.1530/rep.0.1250855)

Allen WR \& Wilsher S 2009 A review of implantation and early placentation in the mare. Placenta 30 1005-1015. (https://doi.org/10.1016/j. placenta.2009.09.007)
Allen WR, Hamilton DW \& Moor RM 1973 The origin of equine endometrial cups. II. Invasion of the endometrium by trophoblast. Anatomical Record 177 485-501. (https://doi.org/10.1002/ar.1091770403)

Allen WR, Wilsher S, Turnbull C, Stewart F, Ousey J, Rossdale PD \& Fowden AL 2002 Influence of maternal size on placental, fetal and postnatal growth in the horse. I. Development in utero. Reproduction 123 445-453. (https://doi.org/10.1530/rep.0.1230445)

Antczak DF, de Mestre AM, Wilsher S \& Allen WR 2013 The equine endometrial cup reaction: a fetomaternal signal of significance. Annual Review of Animal Biosciences 1 419-442. (https://doi.org/10.1146/ annurev-animal-031412-103703)

Bamford NJ, Potter SJ, Harris PA \& Bailey SR 2014 Breed differences in insulin sensitivity and insulinemic responses to oral glucose in horses and ponies of moderate body condition score. Domestic Animal Endocrinology 47 101-107. (https://doi.org/10.1016/j. domaniend.2013.11.001)

Bamford NJ, Potter SJ, Baskerville CL, Harris PA \& Bailey SR 2016 Effect of increased adiposity on insulin sensitivity and adipokine concentrations in different equine breeds adapted to cereal-rich or fat-rich meals. Veterinary Journal 214 14-20. (https://doi.org/10.1016/j.tvjl.2016.02.002)

Barron JK 1995 The effect of maternal age and parity on the racing performance of thoroughbred horses. Equine Veterinary Journal 27 73-75. (https://doi.org/10.1111/j.2042-3306.1995.tb03036.x)

Bosh KA, Powell D, Shelton B \& Zent W 2009 Reproductive performance measures among thoroughbred mares in central Kentucky, during the 2004 mating season. Equine Veterinary Journal 41 883-888. (https://doi. org/10.2746/042516409x456068)

Boyle A G, Timoney JF, Newton J R, Hines M T, Waller A S \& Buchanan BR 2018 Streptococcus equi Infections in Horses: Guidelines for Treatment, Control, and Prevention of Strangles-Revised Consensus Statement. Journal of Veterinary Internal Medicine 32 633-647. (https://doi. org/10.1111/jvim.15043)

Buddington RK, Chizhikov VV, Iskusnykh IY, Sable HJ, Sable JJ, Holloway ZR, Blumenfeld Katzir T, Van der Merwe M, Yakimkova T, Buddington KK et al. 2018 A Phosphatidylserine Source of Docosahexanoic Acid Improves Neurodevelopment and Survival of Preterm Pigs. Nutrients 10 637. (https://doi.org/10.3390/nu10050637)

Carroll CL \& Huntington PJ 1988 Body condition scoring and weight estimation of horses. Equine Veterinary Journal 20 41-45. (https://doi. org/10.1111/j.2042-3306.1988.tb01451.x)

Caure S \& Lebreton P 2004 Ostéochondrose chez le trotteur au sevrage et corrélation avec divers paramètres. Pratique Vétérinaire Équine 36 47-57.

Dawson MJ \& Hone J 2012 Demography and dynamics of three wild horse populations in the Australian Alps. Austral Ecology 37 97-109. (https:// doi.org/10.1111/j.1442-9993.2011.02247.x)

Dewhurst RJ, Scollan ND, Youell SJ, Tweed JKS \& Humphreys MO 2001 Influence of species, cutting date and cutting interval on the fatty acid composition of grasses. Grass and Forage Science 56 68-74. (https://doi. org/10.1046/j.1365-2494.2001.00247.x)

Dini P, Carossino M, Loynachan AT, El-Sheikh Ali H, Wolfsdorf KE, Scoggin KE, Daels P \& Ball BA 2020 Equine hydrallantois is associated with impaired angiogenesis in the placenta. Placenta 93 101-112. (https://doi.org/10.1016/j.placenta.2020.03.001)

Dini P, Kalbfleisch T, Uribe-Salazar JM, Carossino M, Ali HE-S, Loux SC, Esteller-Vico A, Norris JK, Anand L, Scoggin KE et al. 2021 Parental bias in expression and interaction of genes in the equine placenta. PNAS 118 e2006474118. (https://doi.org/10.1073/pnas.2006474118)

Duranthon V \& Chavatte-Palmer P 2018 Long term effects of ART: what do animals tell us? Molecular Reproduction and Development 85 348-368. (https://doi.org/10.1002/mrd.22970)

Elliott C, Morton J \& Chopin J 2009 Factors affecting foal birth weight in Thoroughbred horses. Theriogenology 71 683-689. (https://doi. org/10.1016/j.theriogenology.2008.09.041)

El-Sheikh Ali H, Legacki EL, Loux SC, Esteller-Vico A, Dini P, Scoggin KE, Conley AJ, Stanley SD \& Ball BA 2019 Equine placentitis is associated with a downregulation in myometrial progestin signaling. Biology of Reproduction 101 162-176. (https://doi.org/10.1093/biolre/ioz059)

El-Sheikh Ali H, Boakari YL, Loux SC, Dini P, Scoggin KE, Esteller-Vico A, Kalbfleisch T \& Ball BA 2020a Transcriptomic analysis reveals the key regulators and molecular mechanisms underlying myometrial activation during equine placentitis. Biology of Reproduction 102 1306-1325. (https://doi.org/10.1093/biolre/ioaa020) 
El-Sheikh Ali H, Legacki EL, Scoggin KE, Loux SC, Dini P, Esteller-Vico A Conley AJ, Stanley SD \& Ball BA $2020 b$ Steroid synthesis and metabolism in the equine placenta during placentitis. Reproduction 159 289-302. (https://doi.org/10.1530/REP-19-0420)

Fedorka CE, Ball BA, Scoggin KE, Loux SC, Troedsson MHT \& Adams AA 2019 The feto-maternal immune response to equine placentitis. American Journal of Reproductive Immunology 82 e13179. (https://doi. org/10.1111/aji.13179)

Fernandes CB, Ball BA, Loux SC, Boakari YL, Scoggin KE, El-Sheikh Ali H, Cogliati B \& Esteller-Vico A 2020 Uterine cervix as a fundamental part of the pathogenesis of pregnancy loss associated with ascending placentitis in mares. Theriogenology 145 167-175. (https://doi.org/10.1016/j. theriogenology.2019.10.017)

Flood PF, Betteridge KJ \& Diocee MS 1982 Transmission electron microscopy of horse embryos 3-16 days after ovulation. Journal of Reproduction and Fertility: Supplement 32 319-327.

Fowden AL, Comline RS \& Silver M 1984 Insulin secretion and carbohydrate metabolism during pregnancy in the mare. Equine Veterinary Journal 16 239-246. (https://doi.org/10.1111/j.2042-3306.1984.tb01919.x)

Ganjam VK, Kenney RM \& Flickinger G 1975 Plasma progestagens in cyclic, pregnant and post-partum mares. Journal of Reproduction and Fertility 23 (Supplement) 441-447.

Gibson C, de Ruijter-Villani M \& Stout TAE 2017 Negative uterine asynchrony retards early equine conceptus development and upregulation of placental imprinted genes. Placenta 57 175-182. (https://doi.org/10.1016/j.placenta.2017.07.007)

Gibson C, de Ruijter-Villani M, Bauersachs S \& Stout TAE 2020 Asynchronous embryo transfer followed by comparative transcriptomic analysis of conceptus membranes and endometrium identifies processes important to the establishment of equine pregnancy. International Journal of Molecular Sciences 21 2562. (https://doi.org/10.3390/ijms21072562)

Ginther OJ 1992 Reproductive Biology of the Mare: Basic and Applied Aspects. Estados Unidos: Equiservices.

Henneke DR, Potter GD \& Kreider JL 1984 Body condition during pregnancy and lactation and reproductive efficiency of mares. Theriogenology 21 897-909. (https://doi.org/10.1016/0093-691X(84)90383-2)

Jacob JCF, Haag KT, Santos GO, Oliveira JP, Gastal MO \& Gastal EL 2012 Effect of embryo age and recipient asynchrony on pregnancy rates in a commercial equine embryo transfer program. Theriogenology 77 1159-1166. (https://doi.org/10.1016/j.theriogenology.2011.10.022)

Jacobs RD, Ealy AD, Pennington PM, Pukazhenthi B, Warren LK, Wagner AL, Johnson AK, Hess TM, Knight JW \& Splan RK 2018 Dietary supplementation of algae-derived omega-3 fatty acids influences endometrial and conceptus transcript profiles in mares. Journal of Equine Veterinary Science 62 66-75. (https://doi.org/10.1016/j.jevs.2017.08.001)

Jaworska J \& Janowski T 2019 Expression of proinflammatory cytokines IL$1 \beta$, IL- 6 and TNF $\alpha$ in the retained placenta of mares. Theriogenology $\mathbf{1 2 6}$ 1-7. (https://doi.org/10.1016/j.theriogenology.2018.11.029)

Johnson AK, Clark-Price SC, Choi YH, Hartman DL \& Hinrichs K 2010 Physical and clinicopathologic findings in foals derived by use of somatic cell nuclear transfer: 14 cases (2004-2008). Journal of the American Veterinary Medical Association 236 983-990. (https://doi.org/10.2460/ javma.236.9.983)

Kahler A, McGonnell IM, Smart H, Kowalski AA, Smith KC, Wathes DC \& de Mestre AM 2021 Fetal morphological features and abnormalities associated with equine early pregnancy loss. Equine Veterinary Journal 53 530-541. (https://doi.org/10.1111/evj.13340)

Klewitz J, Struebing C, Rohn K, Goergens A, Martinsson G, Orgies F, Probst J, Hollinshead F, Bollwein H \& Sieme H 2015 Effects of age, parity, and pregnancy abnormalities on foal birth weight and uterine blood flow in the mare. Theriogenology 83 721-729. (https://doi. org/10.1016/j.theriogenology.2014.11.007)

LeBlanc M, Giguere S, Brauer K, Paccamonti D, Horohov D, Lester G, O'Donnel L, Sheerin B, Pablo L \& Rodgerson D 2002 Premature delivery in ascending placentitis is associated with increased expression of placental cytokines and allantoic fluid prostaglandins E2 and F2 $\propto$. Theriogenology 58 841-844. (https://doi.org/10.1016/S0093-691X(02)00822-1)

Loux SC, Robles M, Chavatte-Palmer P \& de Mestre AM 2022 Markers of equine placental differentiation: insights from gene expression studies. Reproduction 163 R39-R54. (https://doi.org/10.1530/REP-21-0115)

Lyle SK 2014 Immunology of infective preterm delivery in the mare. Equine Veterinary Journal 46 661-668. (https://doi.org/10.1111/evj.12243)
Lyle S, Gentry L, Horohov D, Johnson J, Eilts B, Godke R \& Paccamonti D 2009 Preliminary evidence of fetal hypothalamic-pituitary-adrenal axis activation in an experimental model of infective preterm delivery in the mare. Clinical Theriogenology Journal 1238.

Macdonald AA, Chavatte P \& Fowden AL 2000 Scanning electron microscopy of the microcotyledonary placenta of the horse (Equus caballus) in the latter half of gestation. Placenta 21 565-574. (https://doi. org/10.1053/plac.2000.0510)

Madore C, Leyrolle Q, Morel L, Rossitto M, Greenhalgh AD, Delpech JC, Martinat M, Bosch-Bouju C, Bourel J, Rani B et al. 2020 Essential omega-3 fatty acids tune microglial phagocytosis of synaptic elements in the mouse developing brain. Nature Communications 11 6133. (https:// doi.org/10.1038/s41467-020-19861-z)

Martin-Rosset W, Doreau M \& Cloix J 1978 Etude des activités d'un troupeau de poulinières de trait et de leurs poulains au pâturage. Annales de Zootechnie 27 33-45. (https://doi.org/10.1051/animres:19780104)

Martin-Rosset W, Vernet J, Dubroeucq H, Arnaud G, Picard A \& Vermorel M 2008 Variation of fatness and energy content of the body with body condition score in sport horses and its prediction. In Nutrition of the exercising horse. Editors: MT Saastamoinen and W Martin-Rosset; pp. 167-176 Wageningen, Academic Publishers.

Meirelles MG, Veras MM, Alonso MA, de Fátima Guimarães C, Nichi M \& Fernandes CB 2017 Influence of maternal age and parity on placental structure and foal characteristics From birth up to 2 years of age. Journal of Equine Veterinary Science 56 68-79. (https://doi.org/10.1016/j. jevs.2017.03.226)

Mitchell C, Steward KF, Charbonneau ARL, Walsh S, Wilson H, Timoney JF, Wernery U, Joseph M, Craig D, van Maanen K et al. 2021 Globetrotting strangles: the unbridled national and international transmission of Streptococcus equi between horses. Microbial Genomics 7 mgen000528. (https://doi.org/10.1099/mgen.0.000528)

Morris LHA, McCue PM \& Aurich C 2020 Equine endometritis: a review of challenges and new approaches. Reproduction 160 R95-R110. (https:// doi.org/10.1530/REP-19-0478)

Mortensen CJ, Kelley DE \& Warren LK 2011 Supplemental I-arginine shortens gestation length and increases mare uterine blood flow before and after parturition. Journal of Equine Veterinary Science 31 514-520. (https://doi.org/10.1016/j.jevs.2011.01.004)

Oikawa M, Yoshihara T, Kaneko M \& Yoshikawa T 1990 Morphology of equine allantochorion at the tip of the pregnant horn. Journal of Comparative Pathology 103 343-349. (https://doi.org/10.1016/s0021-9975(08)80055-2)

Oriol JG, Betteridge KJ, Hardy J \& Sharom FJ 1993 Structural and developmental relationship between capsular glycoproteins of the horse (Equus caballus) and the donkey (Equus asinus). Equine Veterinary Journal 25 14-18. (https://doi.org/10.1111/j.2042-3306.1993.tb04816.x)

Palmer E, Robles M, Chavatte-Palmer P \& Ricard A 2018 Maternal effects on offspring performance in show jumping. Journal of Equine Veterinary Science 66 221. (https://doi.org/10.1016/j.jevs.2018.05.108)

Paździor K, Rapacz A, Rotkiewicz T \& Raś A 2012 Proliferation and apoptosis in fetal membranes and endometrium during placental retention in heavy draft mares. Journal of Equine Veterinary Science 32 80-84. (https://doi.org/10.1016/j.jevs.2011.06.002)

Pazinato FM, Curcio BDR, Fernandes CG, Santos CA, Feijó LS, Varela AS \& Nogueira CEW 2017 Histomorphometry of the placental vasculature and microcotyledons in thoroughbred mares with chronic laminitis. Theriogenology 91 77-81. (https://doi.org/10.1016/j. theriogenology.2016.12.009)

Peugnet P, Wimel L, Duchamp G, Sandersen C, Camous S, Guillaume D, Dahirel M, Dubois C, Jouneau L, Reigner F et al. 2014 Enhanced or reduced fetal growth induced by embryo transfer into smaller or larger breeds alters post-natal growth and metabolism in pre-weaning horses. PLOS ONE 9 e102044. (https://doi.org/10.1371/journal.pone.0102044)

Peugnet P, Robles M, Mendoza L, Wimel L, Dubois C, Dahirel M, Guillaume D, Camous S, Berthelot V, Toquet MP et al. 2015 Effects of moderate amounts of barley in late pregnancy on growth, glucose metabolism and osteoarticular status of pre-weaning horses. PLOS ONE 10 e0122596. (https://doi.org/10.1371/journal.pone.0122596)

Pozor MA, Sheppard B, Hinrichs K, Kelleman AA, Macpherson ML, Runcan E, Choi YH, Diaw M \& Mathews PM 2016 Placental abnormalities in equine pregnancies generated by SCNT from one donor horse. Theriogenology 86 1573-1582. (https://doi.org/10.1016/j. theriogenology.2016.05.017) 
Rapacz A, Paździor K, Raś A, Rotkiewicz T \& Janowski TE 2012 Retained fetal membranes in heavy draft mares associated with histological abnormalities. Journal of Equine Veterinary Science 32 38-44. (https:// doi.org/10.1016/j.jevs.2011.06.015)

Rapacz-Leonard A, Kankofer M, Leonard M, Wawrzykowski J, Dąbrowska M, Raś A, Paździor-Czapula K \& Janowski T 2015a Differences in extracellular matrix remodeling in the placenta of mares that retain fetal membranes and mares that deliver fetal membranes physiologically. Placenta 36 1167-1177. (https://doi.org/10.1016/j. placenta.2015.07.126)

Rapacz-Leonard A, Raś A, Całka J \& Janowski TE 2015b Expression of oxytocin receptors is greatly reduced in the placenta of heavy mares with retained fetal membranes due to secondary uterine atony. Equine Veterinary Journal 47 623-626. (https://doi.org/10.1111/evj.12426)

Rapacz-Leonard A, Leonard M, Chmielewska-Krzesińska M, Siemieniuch M \& Janowski TE 2020 The oxytocin-prostaglandins pathways in the horse (Equus caballus) placenta during pregnancy, physiological parturition, and parturition with fetal membrane retention. Scientific Reports 10 2089. (https://doi.org/10.1038/s41598-020-59085-1)

Ricketts SW 2003 Early pregnancy failure as seen during the course of equine stud farm practice in Newmarket, 1996-2003. Pferdeheilkunde Equine Medicine 19 633-638. (https://doi.org/10.21836/PEM20030612)

Robles M 2017 Influence du métabolisme maternel sur la fonction placentaire et la santé du poulain. Université Paris-Saclay (ComUE).

Robles M, Gautier C, Mendoza L, Peugnet P, Dubois C, Dahirel M, Lejeune JP, Caudron I, Guenon I, Camous S et al. 2017 Maternal nutrition during pregnancy affects testicular and bone development, glucose metabolism and response to overnutrition in weaned horses up to two years. PLoS ONE 12 e0169295. (https://doi.org/10.1371/journal.pone.0169295)

Robles M, Nouveau E, Gautier C, Mendoza L, Dubois C, Dahirel M, Lagofun B, Aubrière MC, Lejeune JP, Caudron I et al. 2018a Maternal obesity increases insulin resistance, low-grade inflammation and osteochondrosis lesions in foals and yearlings until 18 months of age. PLoS ONE 13 e0190309. (https://doi.org/10.1371/journal.pone.0190309)

Robles M, Peugnet PM, Valentino SA, Dubois C, Dahirel M, Aubrière MC, Reigner F, Serteyn D, Wimel L, Tarrade A et al. 2018b Placental structure and function in different breeds in horses. Theriogenology 108 136-145. (https://doi.org/10.1016/j.theriogenology.2017.11.007)

Robles M, Dubois C, Gautier C, Dahirel M, Guenon I, Bouraima-Lelong H, Viguié C, Wimel L, Couturier-Tarrade A \& Chavatte-Palmer P 2018C Maternal parity affects placental development, growth and metabolism of foals until 1 year and a half. Theriogenology 108 321-330. (https:// doi.org/10.1016/j.theriogenology.2017.12.019)

Robles M, Peugnet PM, Valentino SA, Dubois C, Dahirel M, Aubrière MC, Reigner F, Serteyn D, Wimel L, Couturier-Tarrade A et al. 2018d Placental alterations in structure and function in intra-uterine growth-retarded horses. Equine Veterinary Journal 50 405-414. (https://doi.org/10.1111/evj.12761)

Robles M, Peugnet P, Dubois C, Piumi F, Jouneau L, Bouchez O, Aubrière MC, Dahirel M, Aioun J, Wimel L et al. 2018e Placental function and structure at term is altered in broodmares fed with cereals from mid-gestation. Placenta 64 44-52. (https://doi.org/10.1016/j. placenta.2018.02.003)

Robles M, Couturier-Tarrade A, Derisoud E, Geeverding A, Dubois C, Dahirel M, Aioun J, Prezelin A, Calvez J, Richard C et al. 2019 Effects of dietary arginine supplementation in pregnant mares on maternal metabolism, placental structure and function and foal growth. Scientific Reports 9 6461. (https://doi.org/10.1038/s41598-019-42941-0)

Rose BV, Cabrera-Sharp V, Firth MJ, Barrelet FE, Bate S, Cameron IJ, Crabtree JR, Crowhurst J, McGladdery AJ, Neal H et al. 2016 A method for isolating and culturing placental cells from failed early equine pregnancies. Placenta 38 107-111. (https://doi.org/10.1016/j. placenta.2015.12.014)

Rose BV, Firth M, Morris B, Roach JM, Wathes DC, Verheyen KLP \& de Mestre AM 2018 Descriptive study of current therapeutic practices, clinical reproductive findings and incidence of pregnancy loss in intensively managed thoroughbred mares. Animal Reproduction Science 188 74-84. (https://doi.org/10.1016/j.anireprosci.2017.11.011)

Ryan E, Galvin K, O'Connor TP, Maguire AR \& O'Brien NM 2007 Phytosterol, squalene, tocopherol content and fatty acid profile of selected seeds, grains, and legumes. Plant Foods for Human Nutrition 62 85-91. (https://doi.org/10.1007/s11130-007-0046-8)
Samuel CA, Allen WR \& Steven DH 1974 Studies on the equine placenta. I. Development of the microcotyledons. Journal of Reproduction and Fertility 41 441-445. (https://doi.org/10.1530/jrf.0.0410441)

Samuel CA, Allen WR \& Steven DH 1976 Studies on the equine placenta II. Ultrastructure of the placental barrier. Journal of Reproduction and Fertility 48 257-264. (https://doi.org/10.1530/jrf.0.0480257)

Sessions-Bresnahan DR, Heuberger AL \& Carnevale EM 2018 Obesity in mares promotes uterine inflammation and alters embryo lipid fingerprints and homeostasis. Biology of Reproduction 99 761-772. (https://doi. org/10.1093/biolre/ioy107)

Shilton CA, Kahler A, Davis BW, Crabtree JR, Crowhurst J, McGladdery AJ, Wathes DC, Raudsepp T \& de Mestre AM 2020 Whole genome analysis reveals aneuploidies in early pregnancy loss in the horse. bioRxiv $\mathbf{1 0}$ 13314. (https://doi.org/10.1038/s41598-020-69967-z)

Shook LL, Kislal S \& Edlow AG 2020 Fetal brain and placental programming in maternal obesity: a review of human and animal model studies. Prenatal Diagnosis 40 1126-1137. (https://doi.org/10.1002/pd.5724)

Shrestha N, Sleep SL, Cuffe JSM, Holland OJ, Perkins AV, Yau SY, McAinch AJ \& Hryciw DH 2020 Role of omega-6 and omega-3 fatty acids in fetal programming. Clinical and Experimental Pharmacology and Physiology 47 907-915. (https://doi.org/10.1111/1440-1681.13244)

Steven DH 1982 Placentation in the mare. Journal of Reproduction and Fertility. Supplement 31 41-55.

Stewart F, Allen WR \& Moor RM 1976 Pregnant mare serum gonadotrophin: ratio of follicle-stimulating hormone and luteinizing hormone activities measured by radioreceptor assay. Journal of Endocrinology 71 471-482. (https://doi.org/10.1677/joe.0.0710371)

Thorson JF, Karren BJ, Bauer ML, Cavinder CA, Coverdale JA \& Hammer CJ 2010 Effect of selenium supplementation and plane of nutrition on mares and their foals: foaling data. Journal of Animal Science $\mathbf{8 8}$ 982-990. (https://doi.org/10.2527/jas.2008-1646)

Valenzuela OA, Couturier-Tarrade A, Choi YH, Aubrière MC, Ritthaler J, Chavatte-Palmer P \& Hinrichs K 2018 Impact of equine assisted reproductive technologies (standard embryo transfer or intracytoplasmic sperm injection (ICSI) with in vitro culture and embryo transfer) on placenta and foal morphometry and placental gene expression. Reproduction, Fertility, and Development 30 371-379. (https://doi. org/10.1071/RD16536)

van Niekerk CH \& Allen WR 1975 Early embryonic development in the horse. Journal of Reproduction and Fertility 23 (Supplement) 495-498.

Vander Heyden L, Lejeune JP, Caudron I, Detilleux J, Sandersen C, Chavatte P, Paris J, Deliege B \& Serteyn D 2013 Association of breeding conditions with prevalence of osteochondrosis in foals. Veterinary Record 172 68-68. (https://doi.org/10.1136/vr.101034)

Wang X, Miller DC, Harman R, Antczak DF \& Clark AG 2013 Paternally expressed genes predominate in the placenta. Proceedings of the National Academy of Sciences $\mathbf{1 1 0}$ 10705-10710. (https://doi. org/10.1073/pnas.1308998110)

Warren L \& Vineyard K 2013 Fat and fatty acids. In Equine Applied and Clinical Nutrition, pp. 136-155. Saunders, Elsevier.

Wilsher S \& Allen WR 2003 The effects of maternal age and parity on placental and fetal development in the mare. Equine Veterinary Journal 35 476-483. (https://doi.org/10.2746/042516403775600550)

Wilsher S \& Allen WR 2006 Effects of a Streptococcus equi infection-mediated nutritional insult during mid-gestation in primiparous thoroughbred fillies. Part 1: placental and fetal development. Equine Veterinary Journal 38 549557. (https://doi.org/10.2746/042516406x156497)

Woods L, Perez-Garcia V \& Hemberger M 2018 Regulation of placental development and its impact on fetal growth - new insights from mouse models. Frontiers in Endocrinology 9 570. (https://doi.org/10.3389/ fendo.2018.00570)

Received 29 March 2021

First decision 10 May 2021

Revised manuscript received 10 December 2021

Accepted 12 January 2022 